Comparative Philosophy Volume 6, No. 1 (2015): 24-37

Open Access / ISSN 2151-6014

www.comparativephilosophy.org

\title{
WITTGENSTEIN AND BUDDHISM? ON ALLEGED AFFINITIES WITH ZEN AND MADHYAMAKA
}

\author{
FLORIAN DEMONT-BIAGGI
}

\begin{abstract}
Buddhism is popular nowadays and so it becomes in analytic philosophy, as an increasing number of publications on possible intersections between analytic philosophy and Buddhism suggests. The paper focuses on two possible intersections between the philosophy of Ludwig Wittgenstein and Buddhism. Drawing mainly on an article by Rupert Read, it is first assessed whether there are affinities between Wittgenstein and Zen. After that follows a discussion of alleged affinities between Wittgenstein and Indian Madhyamaka. The upshot of this paper will be that, while alleged affinities between Wittgenstein and at least one important variety of Zen lead to a dead end, constructively engaging Wittgenstein and Indian Madhyamaka is surprisingly fruitful if we make two specific exegetical choices. The first exegetical choice is to focus on Wittgenstein's Big Typescript (and related documents). The second exegetical choice is to read Nāgārjuna according to Chandrakīrti and Lama Tsong Khapa (and all three as expounded by Jay Garfield). Under the assumption that these choices are good, further investigations to charter this new terrain appear justified.
\end{abstract}

Keywords: Wittgenstein, Nāgārjuna, Zen, Dōgen, meta-metaphysics, conventional reality

Contemporary philosophy is much concerned with meta-metaphysical questions, reintroducing central issues about the relation between reality and human concepts. Both, Wittgenstein and Buddhist thinkers after Nāgārjuna have worked hard on these issues. It has been argued by Rupert Read, Jay Garfield and others that there are interesting parallels between Wittgenstein's and Nāgārjuna's (and his followers') views on reality. There is, of course, a legitimate hope that if a great European philosopher and an influential strand of Buddhist thought have developed comparable - and, as will be shown, largely compatible - views on reality and human concepts, then these views might further our understanding and should, hence, become available to contemporary debates on meta-metaphysics.

Constructively engaging Wittgenstein and Buddhist thought after Nāgārjuna seems promising, because they argue that we should abandon much of metaphysics as traditionally conceived in European and orthodox Hindu philosophy respectively. But

DEMONT-BIAGGI, Florian: Postdoc Assistant, Militärakademie and der Eidgenössischen Technischen Hochschule Zürich, Switzerland. Email: florian.demont@milak.ethz.ch 
the two do so coming from different directions; while Wittgenstein focuses on language, Nāgārjuna is usually read as being preoccupied with fundamental issues of ontology. So, we should ask whether they have reasons which are compatible with and supportive of each other. In a first section, this article identifies a dead end and suggests, in a second section, a more promising line of inquiry.

\section{RUPERT READ ON WITTGENSTEIN AND ZEN}

Some Philosophers interested in affinities between Wittgenstein and Buddhism lay the focus on Zen Buddhism, a tradition which counts Nāgārjuna among its most important ancestors. A recent paper that aligns Wittgenstein and Zen is Rupert Read's 'Wittgenstein and Zen Buddhism: One Practice, No Dogma'. Read's main thesis is that Wittgenstein's philosophical method and Zen practice-especially Japanese Sōtō Zen practice - aim at teaching people to realize that they are constantly deluded by certain strings of words. Wittgenstein's method and Zen practice are also thought to teach that simply realizing how one is deluded by words is enough to dispel the problems they give rise to. There is, Read argues, no further soteriological, ethical or other goal to be attained. ${ }^{1}$

Even though Read's interpretation of Wittgenstein's views in the Tractatus and the claim that the very same views also lie at the heart of Wittgenstein's later works are controversial, I shall not take sides on these issues, but focus on how Read compares his Wittgenstein's views with Zen. This allows me, I hope, to make my arguments appealing to as many readers of Wittgenstein as possible. So, for the sake of argument (if you disagree with Read) or by virtue of its sheer truth (if you agree with Read) Wittgenstein's views in the Tractatus and elsewhere will be assumed to be as Read writes:

[W] hat Wittgenstein was aiming for was coming to know one's way about the temptations one suffers to say things that one will come to see as not saying at all. Coming to know, coming to terms with the temptations to which you are subject-and thus being liberated from them. ${ }^{2}$

Further down on the same page, Read gives his characterization of Zen Buddhism:

What is Zen Buddhism? It is not a doctrine nor a dogma. It is more of a practice, a way. Let's say: in Rinzai, it is the attainment of enlightenment through dwelling on kōans until the power of one's ego intellect is "broken" by them and the mind flows freely; in Sōtō, just sitting (shikantaza) until, through meditation, the same goal is attained. Why is it so hard? Because the overwhelming temptation is to try to achieve the goal. This will make one impatient with the present moment. Whereas, in truth, the "goal" is precisely to be at

\footnotetext{
${ }^{1}$ Read establishes his point about Wittgenstein on $16-17$ of his 2009 . Following that, he aligns the aims of Zen practice with Wittgenstein's method on 18-20.

${ }^{2}$ Read 2009, 16-17.
} 
ease in and with the present moment. The skillful means of Zen are actually already the goal, surreptitiously. But this leads to the grave danger that one will attach to those means.

This also further explains why the route taken in Zen must be indirect, why the practitioner has to be deceived into the truth. There could not possibly be any such truth as one imagines there is in the direct route. For what one has to be cured of is exactly the temptation to think that there is anything, even anything unstateable/ineffable, which is the truth of Buddhism, the truth of life. The means are the end-but one must not attach to the means either. ${ }^{3}$

Based on these characterizations of Wittgenstein's aim and Zen, Read already declares the affinities to be evident. ${ }^{4}$

Most of the time, Read focuses specifically on Sōtō Zen as we find it in Japan and as it was propagated in the West by Shunryu Suzuki, Taisen Deshimaru, Dainin Katagiri and their followers. But he also draws on Indian Madhyamaka and Rinzai teachings and he includes vague allusions to Thich Nhat Hanh, Dzogchen and Mahāmudrā. In order to keep things clear, I shall focus on Japanese Sōtō Zen as propagated by Eihei Dōgen, the founder of that school.

There are passages in Dōgen's Shōbōgenzō that do not go together well with what Read finds in Wittgenstein's writings. Read repeatedly claims that, according to Zen, truth cannot be put into words: ${ }^{5}$

In Zen and Wittgensteinian practice, one does not believe that the truth can be said. But one does not believe either that there is an unsayable truth.

This is not true for the entire Zen tradition. In chapter 46 of the Shōbōgenzō, Dōgen makes clear that the nature of reality can also be transmitted through words. Having commented on an exchange between Bodhidharma and his disciples, Dōgen writes:

On this basis, even the speaking of words is individual instances of the springing out in which master and disciple experience the same state. And even the action of listening is individual instances of the springing out in which master and disciple experience the same state. Investigation of the same state by master and disciple is the entanglement of Buddhist patriarchs. ${ }^{6}$

When Dōgen speaks about the same state in this context, he means enlightenment, which is certified in the exchange between master and disciple. And because the exchange between Bodhidharma and his disciples is an exchange in which words are spoken and listened to, enlightenment - knowledge of the nature of reality - can be expressed in words. This flatly contradicts Read's view of the matter when he writes:

\footnotetext{
${ }^{3}$ Read, 2009, 17.

${ }^{4}$ Read 2009, 17; having characterized Zen as quoted above, Read immediately adds: "The deep similarities to a vital minority tradition in Western philosophy, a tradition at whose culmination stands Wittgenstein, are evident."

${ }^{5}$ Read 2009, 22.

${ }^{6}$ Cross and Nishijima 2008 (Vol. 3), 53.
} 
What Wittgensteinian psychology/therapy/"philosophy"/spiritual practice and Zen spiritual practice/psychology/therapy/thinking are interested in engendering is not anything that one can say. ${ }^{7}$

Still, Read indicates passages of contemporary Sōtō Zen teachers who seem to endorse the view he holds. He might thus reply that my objection is based on a misreading or that the passage I have cited is an exception. There are, however, other passages which are hard to square with Read's claims about Zen. In chapter 2 of the Shōbōgenzō, to give another example, Dōgen quotes his late master and then adds:

This is the speech of prajña (transmitted) by Buddhist patriarchs from rightful successor to rightful successor. ${ }^{8}$

It is hard to see how Read can deal with these passages from the canonical Shōbōgenzō and convincingly claim that, according to Zen, the truth cannot be said.

Of course, I am not concerned with Zen as a whole, but focus on Japanese Sōtō Zen instead. There are two reasons for this. First, Read himself seems to draw predominantly from Sōtō Zen sources associated with Dōgen. Second, Dōgen's writings on Zen are canonical - if Read is wrong about them, the odds are good that he is also wrong regarding the interpretation of other Zen writings.

So far, I have produced two passages from Dōgen which are hard to be made consistent with Read's claims about Zen. And there is more evidence in Dōgen's writings, which show that Read's position is indeed questionable. Consider again the alleged common ground between Wittgenstein's method and Zen practice: both are said to aim at teaching people to realize that they are constantly deluded by certain strings of words. This is, however, not precisely true for Dōgen. Dōgen never was influenced by any sort of linguistic turn and never partook in one-quite unlike Wittgenstein. For Dōgen, the inclination to be deluded is triggered by any experience-not only by strings of words. Therefore, Zen practice according to Dōgen is, if similar at all, much more inclusive than Wittgenstein's method. In chapter 2 of the Shōbōgenzō, Dōgen explicitly claims that experiencing (material) form, feeling, perception, volition and consciousness with the right state of body and mind, is nothing else than highest wisdom, enlightenment:

"When Bodhisattva Avalokiteśvara practices the profound prajñā-pāramitā, the whole body reflects that the five aggregates are totally empty." The five aggregates are form, feeling, perception, volition, and consciousness. They are five instances of prajñā. Reflection is prajñ $\bar{a}$ itself. ${ }^{9}$

\footnotetext{
${ }^{7}$ Read 2009, 22.

${ }^{8}$ Cross and Nishijima 2007 (Vol. 1), 34; prajña refers to the highest wisdom.

${ }^{9}$ Cross and Nishijima 2007 (Vol. 1), 31; the passage refers to the five aggregates which constitute personal identity according to Buddhist psychology.
} 
This implies, of course, that experiencing (material) form, feeling, perception, volition and consciousness with a different state of mind is delusion. So, delusion is not predominantly triggered by words.

One might think that this is not a big problem for Read, because once Wittgenstein has managed to convince us that we are inclined to be deluded by words, we will be able to track these inclinations in other experiences as well. And, as one might want to conclude, Dōgen's Zen practice is no more inclusive at the end of the day than Wittgenstein's method. So, would such a reply help support Read's case?

I think that a reply along these lines still downplays the differences between Dōgen and Wittgenstein. Wittgenstein's method is language-based: we must, according to Read, wrestle the propositions of the Tractatus down to the ground in order to realize our inclinations to be deluded by words. ${ }^{10}$ Everybody who can read can, in principle, use the Tractatus to attain the right state of mind that allows one to realize that one did not have a problem all along, that one was merely chasing ghosts. For Dōgen, the way to obtain the right state of mind is very different. The right state of mind is also a state of the body, because there is no difference between body and mind for him: "body and mind are not divided". ${ }^{11}$ It is even appropriate to coin the artificial expression 'body-and-mind' to express Dōgen's subtle notion of a right state of mind. Regarding the relation between the body-and-mind and ordinary conventions, Dōgen writes:

Thus, with regard to the lineage that simply takes the human methods to be the BuddhaDharma and (the lineage) that narrowly takes human methods to be the Buddha-Dharma, never permit that either the former or the latter are the Buddha's disciples. They are only ordinary beings as the result of karma. They have never experienced the hearing of Dharma through body-and-mind, and they have never possessed a body-and-mind that has practiced the truth. ${ }^{12}$

Now, Read's Wittgenstein arguably suggests a different practice, one for which the body plays no role at all:

Philosophy, for Wittgenstein, is not trying to change the way that one thinks. Instead, it is letting oneself think the way one does; accepting that one is tempted to think in all these ways; noting it. $^{13}$

Furthermore, in the Fukanzazengi, Dōgen makes explicit recommendations that contradict Read's Wittgenstein:

Cast aside all involvements. Give the myriad things a rest. Do not think of good and bad. Do not consider right and wrong. Stop the driving movement of mind, will, consciousness. Cease intellectual considerations through images, thoughts, and reflections. ${ }^{14}$

\footnotetext{
${ }^{10}$ Read 2009, 15.

${ }^{11}$ Cross and Nishijima 2007 (Vol. 1), 15.

12 Cross and Nishijima 2008 (Vol. 2), 50.

${ }^{13}$ Read 2009, 16.
} 
There is, however, yet another respect in which Dōgen recommends a practice that is different from what Read's Wittgenstein suggests. According to Dōgen only nuns and monks attain the right state of mind and body. Unless a layperson quits home, shaves her or his head and partakes in monastic discipline, there is no way that such a person can attain highest wisdom. ${ }^{15}$ Dōgen writes:

None has succeeded to the right action of the Buddha-Dharma, and none has received the authentic transmission of the great truth of the Buddha-Dharma, without leaving family life. $^{16}$

When Dōgen speaks about Zen practice, he is actually referring to a rigorous monastic discipline which is nothing at all like wrestling with the propositions of the Tractatus. Dōgen's Zen practice is a monastic practice for which meticulous rules govern all aspects of daily life ranging from how monks are supposed to go to the toilet to how the temple is to be organised. For Dōgen, blending in with others around us and following the monastic standards together is pivotal. This is why he begins his Model for Engaging the Way as follows:

All buddhas and all ancestors are within the Way and engage it; without the Way they would not engage it. The dharma exists and they appear; without the dharma they do not appear. Therefore, when the assembly is sitting, sit together with them; as the assembly (gradually) lies down, lie down also. In activity and stillness at one with the community, throughout deaths and rebirths do not separate from the monastery. Standing out has no benefit; being different from others is not our conduct. ${ }^{17}$

Here again, the sort of practice Read's Wittgenstein stands for is obviously very different; regarding the Tractatus Read writes:

To understand Wittgenstein's point in producing such a puzzling text, one must overcome those propositions, wrestle them down to the ground and realize that one was wrestling only specters. ${ }^{18}$

Taking in all the considerations mentioned so far, not many affinities between Wittgenstein's method and Japanese Sōtō Zen practice - as envisaged by its founder Dōgen - remain. Both may lead people to recognise that they have inclinations that tend to mislead them. But Wittgenstein's method and Zen practice pursue these aims in very different ways. Read has failed to make clear why Wittgenstein's methods should be closer in spirit to Zen practice than to any other soteriological practice,

\footnotetext{
${ }^{14}$ Cross and Nishijima 2007 (Vol. 1), 364.

${ }^{15}$ Such claims abound in Dōgen's writings. Chapters of the Shōbōgenzō on this issue include: Chs. 73, 83 and 86.

${ }^{16}$ Cross and Nishijima 2008 (Vol. 4), 14.

${ }^{17}$ Leighton and Okamura 1996, 63.

${ }^{18}$ Read 2009, 15.
} 
which is based on a story about human inclinations, about how they mislead people and how some sort of soteriological insight dispels the bad effects of these inclinations. There is, hence, no special affinity between Zen and Read's Wittgenstein - at least if we focus on the canonical writings of the Japanese Sōtō Zen tradition. And even if Read found other Zen traditions for which his claims prove justified, the claims would still be wrong concerning one of the most prominent traditions. If we take into consideration that Read's interpretation of Wittgenstein remains controversial and that alternative readings - such as the one defended by Peter Hacker - do reject a therapeutic aim that informs all of Wittgenstein's works, the prospects of Read's position are not promising at all. ${ }^{19}$

\section{WITTGENSTEIN AND MADHYAMAKA}

We now turn to another possible affinity between Wittgenstein and Buddhism. In the article discussed above, Rupert Read mentions the Indian Madhyamaka philosopher Chandrakirti and suggests that his attitude towards metaphysics is basically the same as Wittgenstein's. ${ }^{20}$ I find this an important insight and in the following section I shall explain why and to what extent Read is probably right about this.

Chandrakīrti is best known as an expounder of the works of Nāgārjuna, the fountainhead of Mahāyāna Buddhism. Nāgārjuna's teachings have been very influential in Asia and many Buddhist schools see him as an important ancestorDōgen's Zen is as firmly rooted in Nāgārjuna's teachings as are all schools of Tibetan Buddhism. If there are affinities between how Wittgenstein and Indian Madhyamaka see metaphysics, their common points should be highly relevant for contemporary debates in meta-metaphysics, as they might bring new philosophical perspectives to bear on these debates.

The affinity between Wittgenstein and Buddhism most relevant here has already been identified by Read, who claims that reification is an issue that both Wittgenstein and Indian Madhyamaka are deeply concerned about. ${ }^{21}$ The idea here is that both sides offer distinct arguments for abandoning large parts of traditional metaphysics. And I would add that through constructively engaging both views we can hope to gain access to a novel set of claims and arguments to contribute to ongoing debates in meta-metaphysics (and possibly the philosophy of logic).

Let us begin with Wittgenstein. When Wittgenstein joined Waismann and Schlick in Vienna, he had this to say about metaphysics:

Words like 'truth', 'sense', 'reality' have a peculiar fascination. The philosopher would like to penetrate to the deeper meaning which he dimly feels to lie behind these words. For this purpose he asks: What is the essence of truth? What is the essence of the real? We are no longer tempted to give answers to these questions. But what underlies this

\footnotetext{
${ }^{19}$ Cf., Hacker's contribution to Crary and Read 2000.

${ }^{20}$ Read 2009, 21.

${ }^{21}$ Read 2009, 21.
} 
obscure search? What force imposes these questions on us? We arrive here at an important point, but one very difficult to clear up. ${ }^{22}$

And a bit further down in the same text, Wittgenstein tells us what is wrong with such metaphysical questions. Referring to Frege's discussion of numbers, he writes:

The question 'What is a number if it is not a sign?' arises from a mistaken grammatical background; for to this 'What?' we imagine a 'This', or we expect some 'This' in answer. Even the tone of this question recalls the tone of Augustine's question 'What is time?' A substantive [i.e. a noun] misleads us into looking for a substance. ${ }^{23}$

These passages clearly show that reification is important for Wittgenstein and that linguistic reification is at the root of what he takes to be confused metaphysics.

So, what does Indian Madhyamika have to say about metaphysics? Here, matters are a bit more complicated. Nāgārjuna's writings are notoriously difficult to interpret. He has been called a nihilist, a radical sceptic and, more recently, a dialethist (i.e. somebody who claims that some contradictions are true). Due to the vast variety of issues involved in this, I shall focus on Jay Garfield's reading of Nāgārjuna and assume that it is sufficiently accurate for present purposes. In his Empty Words. Buddhist Philosophy and Cross-Cultural Interpretation, Garfield draws attention to the fact that both, Wittgenstein and Nāgārjuna, have been supposed to argue for radical forms of scepticism. He explains that both have reservations about metaphysical disputes surrounding the question whether reality is dependent on or independent of human thought or talk. And concerning Wittgenstein, as we have just seen, this makes much sense: if metaphysical what-questions are misleading, further questions about reality, which such questions are meant to probe, are most likely confused as well.

So, what does Nāgārjuna's scepticism amount to? Garfield produces the following passages (verses 39 and 73) from the Śn̈nyatāsaptati:

Since ultimately action is empty,

If it is understood it is seen to be that way.

Since action does not exist,

That which arises from action does not exist either.

When one understands that this arises from that,

All of the false views are thereby refuted.

Hatred, anger and delusion are eliminated,

And undefiled, one achieves nirvana. ${ }^{24}$

For most readers, this passage requires explanation. Actions have causes and effects and, as Nāgārjuna argues, are empty. By this Nāgārjuna means to say that actions do

${ }^{22}$ Waismann and Wittgenstein 2003, 487.

${ }^{23}$ Waismann and Wittgenstein 2003, 491.

${ }^{24}$ Quoted by Garfield 2003, 5. 
not have essences, but that they have causal roles nevertheless. So, Nāgārjuna denies at the very least that the actions we witness in the world have any sort of nature, essence or substance independent of their causal roles. One sort of false view-call it the eternalist view-claims that there are such essences and that explaining causal relations requires them. Another sort of false view, one that is only implied in the quote above, is the nihilist view that there are neither essences nor causal relations.

The quote also reveals a central point of Nāgārjuna's soteriology. Eternalism and nihilism are thought to nourish hatred, anger and delusion, whereas Nāgārjuna's middle way between the extremes is thought to be ethically and soteriologically undefiled and therefore leads to the soteriological goal, the extinction of suffering. From this we learn that Nāgārjuna's philosophy, especially his scepticism, is soteriologically motivated and that, for him, philosophy is ancillary to religion.

As mentioned before, for Garfield the point of contact between Nāgārjuna and Wittgenstein is that both defend a strikingly similar contempt for reifications in philosophy. And Read seems to go a step further when he suggests that Indian Madhyamaka, as we find it in Chandrakīrti, endorses basically the same dismissive attitude towards metaphysics as Wittgenstein. So, to what extent does Wittgenstein's position compare to Nāgārjuna's?

First of all, scepticism is always about doubting that some claim is sufficiently warranted and, so the typical sceptic claims, the grounds for the doubt cannot be removed. Scepticism about a set of claims thus involves two distinct attitudes: 1) doubting that there is warrant for any claim within the set and 2) claiming that these doubts cannot be removed by referring to any member of the set or the entire set. Applied to Nāgārjuna's case, we find that he is a sceptic about essences. He explicitly doubts warrant for any claim about the existence of essences and holds that these doubts cannot be removed by referring to any particular essence or by referring to anything else associated with the set of claims about essences (or the entire set).

But Nāgārjuna is not only a sceptic about essences. He claims that a wise person does not endorse any metaphysical view concerning them:

To say "it exists" is to reify.

To say "it does not exist" is to adopt the view of nihilism.

Therefore a wise person

Does not subscribe to "it exists" or "it does not exist".

"Whatever exists essentially

Cannot be non-existent" is reification.

"It existed before, but does not now"

Entails the error of nihilism. ${ }^{25}$

This does not lead Nāgārjuna to deny existence, for he explicitly claims (e.g. in the passage cited before) that any this arises from a that - that there are causal relations and that they are constitutive. To say that causal relations are constitutive is to say

${ }^{25}$ Garfield and Samten 2006, 324-5. 
that the causal relation between a cause and an effect is necessary and sufficient for the cause and the effect to exist. To exist is to have causal relations to other things and these relations do not require any sort of independent natures or essences. Lama Tsongkhapa interprets the two verses on essences along these lines and writes:

Whatever is said to exist essentially, since there could be no change in its essence, could never become nonexistent. Therefore, to maintain that something exists essentially is to adopt the view of reification. But to maintain mere existence is not to do so. ${ }^{26}$

Wittgenstein, as we have seen, also argues against metaphysical essences or substances which are independent of thought and talk. Already in the Tractatus he explicitly claims that language takes care of itself ${ }^{27}$ and in a later passage quoted above he holds that it is confused to think that expressions should be compared to reality in order to decide whether language has been used correctly. So, Wittgenstein rejects the claim that language latches onto reality and that reality justifies language use. He thus rejects the idea that language must be grounded in metaphysical profundities. An upshot from this is the claim that particular words have a particular usage built into them. We might hear a word, associate something particular with it and still, the correct application of the word might differ:

Then what sort of mistake did I make; was it what we should like to express by saying: I should have thought the picture forced a particular use on me? [...] What is essential is to see that the same thing can come before our minds when we hear the word and the application still be different. Has it the same meaning both times? I think we shall say not. $^{28}$

Still, Wittgenstein is not a nihilist and retains the idea that there is a clear distinction between correct and incorrect language use. ${ }^{29}$ Wittgenstein explains this most succinctly in his Big Typescript:

Again and again my mistake consists in forgetting that it is all its rules that characterize a game, a language, and that these rules are not answerable to a reality in the sense that they are controlled by it, and that we could have doubts whether a particular rule is necessary or correct. [...]

Grammar is not answerable to any reality.

(Grammar is not accountable to reality.)

Can this ostensive explanation collide with the rest of the rules for the use of the word? Actually, rules can't collide, unless they contradict each other. What is more, they

\footnotetext{
${ }^{26}$ Ibid.

${ }^{27}$ Wittgenstein 1922, 117.

${ }^{28}$ Wittgenstein 1958, §140, 55.

${ }^{29}$ Cf., Wittgenstein's Philosophical Grammar, especially passages like VII:85 and 89.
} 
determine a meaning; they are not answerable to one and thus can't contradict it. ( (Cf. the remark that an ostensive explanation is one of the rules that are valid for a word.) $)^{30}$

Once we understand how ostensive explanations work, we will not be tempted to search for metaphysical profundities anymore, but see the rules making up a grammar for what they are: conventional reality as it presents itself in language use.

Based on this, we can interpret Wittgenstein in a way which suggests a further affinity with Nāgārjuna. The distinction between correct and incorrect language use is shared between language users, there is mutual agreement on what makes sense. The agreement is characterised in terms of an internal relation between rules and actions. Language use is rule-governed and the rules govern actions (particular language uses) without requiring anything further to mediate between them. ${ }^{31}$ So, just as much as causal relations are constitutive of their relata in Nāgārjuna's view, the internal relation between rules and actions is constitutive of its relata in a very similar way.

Apart from this similarity between Wittgenstein's and Nāgārjuna's attitudes towards metaphysics, we have also found what seems to stand between them. There appears to be a difference between grammar, construed as the rules governing language use, and karman, construed as an intricate network of causal relations which are constitutive of their relata. And that difference has, as far as I can see, one central element: internal relations can be defeasible and causal relations cannot. ${ }^{32}$ Some causal relations can be rendered ineffective when another causal relation (or several) interferes with it, but this does not amount to a defeasibility of the causal relation. So, Wittgenstein's proposal remains on the level of (defeasible) linguistic convention and Nāgārjuna's is ontological, focusing on nomological interdependence.

Regarding the constructive engagement of Wittgenstein and Nāgārjuna, this is good news. After all, they offer two distinct approaches - one linguistic and one ontological-leading both to a metaphysics without essences that offers an analysis of conventional reality based on internal relations. That in itself is an important point, because it may contribute to ongoing disputes in meta-metaphysics.

But there might be more that we can gain from comparing Wittgenstein and Nāgārjuna. We have not clarified to which extent the two perspectives - the linguistic and the ontological-are compatible with each other. Maybe there is a way of interpreting Nāgārjuna's position in ontology that further erodes the differences between his and Wittgenstein's proposal?

The interpretation of causal relations in Nāgārjuna's account that was chosen for the purposes of this article goes back to Chandrakîrti and was later endorsed by Lama Tsong Khapa, the founder of the Gelug school of Tibetan Buddhism. The philosophical school they form is usually called Prāsāngika-Madhyamaka and their official doctrine is a form of conventionalism which Tsong Khapa characterises as follows:

\footnotetext{
${ }^{30}$ Wittgenstein 2005, 183.

${ }^{31}$ Baker and Hacker 1984, 106ff.

32 Baker and Hacker 1984, 111-112.
} 
[E]xistents are merely names and symbols and conventions, as has been explained many times. 'Being name only' means, as I have previously explained, that if the conventional meaning is investigated, nothing is found; not that name exists but the object does not, nor that without a name no object exists. So, not everything posited nominally by a conventionally designative mind as conventionally existent is accepted; but nor is anything not posited through the power of a conventionally designative mind as conventionally existent accepted as empirically real. ${ }^{33}$

In this passage Lama Tsong Khapa suggests that mere existence is also established by conventions. He does, however, mention that not everything named does indeed exist, but that nothing may count as empirically real that is not named. The distinction between correct and incorrect within the domain of the conventional is drawn with regard to what counts as being delivered as correct by unimpaired sense faculties. ${ }^{34}$ So, naming, according to Lama Tsong Khapa, is in fact the same as ostensively explaining what a name stands for. And this is astonishingly similar to what Wittgenstein expresses in the passage from the Big Typescript quoted above, where ostensive explanations have a central place as one sort of rules governing the usage of a word.

But even with these further explanations in place, it remains somewhat unclear whether the conventions Lama Tsong Khapa envisages adjudicate matters of correctness in exactly the same way as Wittgenstein's rules. The similarity breaks down if it turned out, for example, that Tsong Khapa's views on sense faculties (and psychology in general) are not compatible with what Wittgenstein has to say about psychological concepts. More research is required to decide this matter. But we may indeed, based on the passages cited and the interpretations given, endorse Garfield's and Read's idea that Wittgenstein and Nāgārjuna (at least if read along the lines suggested by Chandrakīrti and Lama Tsong Khapa) have basically the same attitude towards metaphysics. One simply prefers to express his attitude in terms of language and the other prefers to focus on causality. The principal upshot from constructively engaging the two perspectives is, however, clear: they offer two more or less distinct approaches - one linguistic and one ontological-leading both to a metaphysics of conventional reality based on internal relations (and without substances or essences). Both perspectives do endorse ostensive explanation as a valid way of explaining naming. But whether this endorsement can serve as a link to bind together the linguistic and the ontological perspective in order to form a more inclusive position remains to be shown.

So, once we compare what is indeed comparable, we do find an affinity between Wittgenstein and the Prāsāngika-Madhyamaka school of Buddhism. That affinity might be set out more clearly by scholars who are both experts on Wittgenstein and on Buddhism, but we should be careful not to read too much into the affinity. After all, some important Buddhist texts (especially some important writings by Nāgārjuna and Dōgen) contain contradictions and some of these contradictions must, at least

${ }^{33}$ As quoted by Garfield 2003, 11.

${ }^{34}$ Garfield and Samten 2006, 485. 
according to some experts, be taken at face value. It is argued that these writings are best regarded as employing a deviant (that is, paraconsistent) logic. ${ }^{35}$ Wittgenstein, on the other hand, does not regard a system as an alternative logic, if it explicitly allows the derivation of contradictions. ${ }^{36}$ This is, therefore, an important topic for further investigations, but it does not affect the result of the constructive engagement.

There is, to summarize the main point of this article, certainly enough common ground to perceive an important line of reasoning in what Wittgenstein and the Prāsāngika-Madhyamaka school have to teach us about reification and our general tendency to seek out metaphysical profundities. Both Wittgenstein and the Prāsāngika-Madhyamaka school recommend an understanding of reality that shies away from essences and pays great attention to tendencies to reify and to seek deep metaphysical truths beneath conventional reality. Constructively engaging both perspectives yields linguistic and ontological arguments that may be relevant for antiessentialist positions in ongoing meta-metaphysical debates. And once we understand more precisely what the two perspectives have to say about contradictions, we will also be in a position to spell out possible consequences this might have for contemporary debates in the philosophy of logic.

\section{ACKNOWLEDGEMENTS}

I would like to thank two anonymous referees of Comparative Philosophy for their helpful comments and suggestions on an earlier version of this article.

\section{REFERENCES}

Baker, Gordon and Hacker, P.M.S. (1984), Scepticism, Rules \& Language (Oxford: Blackwell).

Crary, Alice and Read, Rupert (eds) (2000), The New Wittgenstein (London: Routledge)

Cross, Chodo and Nishijima, Gudo Wafu (trans) (2008-9), Shōbōgenzō. The True Dharma-Eye Treasury (Berkeley: Numata Center for Buddhist Translation and Research)

Deguchi, Yasuo; Garfield, Jay F. and Priest, Graham (2008), "The Way of the Dialetheist: Contradictions in Buddhism", Philosophy East and West, 58(3): 395402

Garfield, Jay F. (2003), Empty Words. Buddhist Philosophy and Cross-Cultural Interpretation (Oxford: Oxford University Press).

${ }^{35}$ Cf. Deguchi, Garfield and Priest 2008.

${ }^{36}$ Cf. Glock 1996, 49, but see also 90-92 where Glock summarises Wittgenstein's liberal attitude towards hidden contradictions. 
- (2010), "Taking Conventional Truth Seriously: Authority Regarding Deceptive Reality", Philosophy East and West, 60(3): 341-354.

Garfield, Jay F. and Samten, Geshe Ngawang (trans) (2006), Ocean of Reasoning. A Great Commentary on Nāgārjuna's Mūlamadhyamakakārikā (Oxford: OUP).

Glock, Hans-Johann (1996), A Wittgenstein Dictionary (Oxford: Blackwell).

Read, Rupert (2009), "Wittgenstein and Zen Buddhism: One Practice, No Dogma" In: D'Amato, M.; Garfield, J. and Tillemans, T. (eds) (2009), Pointing at the Moon (Oxford: OUP), 13-23.

Katagiri, Dainin (2000), You Have to Say Something (Boston: Shambala).

Leighton, Dan and Okamura, Shohaku (1996), Doggen's Pure Standards for the Zen Community. A Translation of Eihei Shingi (Albany: State University of New York Press).

Suzuki, Shunryu (2002), Not Always So: Practicing the True Spirit of Zen, Brown, E. (ed.) (New York: Harper Collins).

Waismann, Friedrich Wittgenstein, Ludwig (2003), The Voices of Wittgenstein. The Vienna Circle, edited by Gordon Baker (London: Routledge)

Wittgenstein, Ludwig (1922), Tractatus Logico-Philosophicus, translated by C. K. Ogden (London: Routledge).

- (1958), Philosophical Investigations (Oxford: Blackwell).

- (1969), Philosophical Grammar (Oxford: Blackwell).

- (2005), The Big Typescript: TS 213 (Oxford: Blackwell). 